\title{
MARKER ASSISTED SELECTION FOR HERBICIDE RESISTANCE IN SUNFLOWER
}

\author{
Bulos, M. , Sala, C.A., Altieri, E., Ramos, M.L. \\ Departamento de Biotecnología, Nidera S.A., Casilla de Correo 6, \\ CP., 2600 Venado Tuerto, Santa Fe, Argentina
}

Received: August 30, 2013 Accepted: December 05, 2013

\section{SUMMARY}

IMISUN, SURES, and CLPlus are three herbicide tolerance traits in sunflower (Helianthus annuus L.) which are determined by the expression of different alleles at the same locus, Ahasl1. Introgression of these genes into high yielding sunflower germplasm should be complemented through the use of molecular markers in order to unambiguously identify the different alleles involved in tolerance. The aim of this work was to present a set of allele specific molecular markers for the different herbicide resistant traits of sunflower, which can be used with various technological platforms, and applied to different objectives in a breeding program. The Ahasl1 gene sequences from lines carrying different alleles for susceptibility or resistance showed single nucleotide polymorphisms and length variations for a simple sequence repeat. These differences were utilized to develop three types of PCR markers (SSRs, CAPS and SNPs) which allow the precise identification of each allele at the Ahasl1 locus. Usefulness of these markers with respect to the application of phenotypic selection for herbicide tolerance, and the strategic implementation of these techniques for developing inbred lines with herbicide resistance is discussed.

\section{Key words: Helianthus annuus, AHAS, imidazolinone, sulfonylurea, alelle specific markers}

\section{INTRODUCTION}

Traditionally, sunflower producers have had few herbicides for controlling broadleaf weeds. Weed control was commonly achieved with pre-plant incorporated and pre-emergence herbicides which did not provide adequate control. For this reason, gene discovery and trait development for herbicide tolerance (HT) in sunflower, particularly to herbicides such as imidazolinones (IMI) and sulfonylureas (SU), was an active area of research during the past decade to provide non-GMO strategies for weed control in this crop (Sala et al., 2012b). IMI and SU herbicides have been

* Corresponding author: Tel/Fax: +54 3462 423196; e-mail: mbulos@nidera.com.ar 
demonstrated to have a broad spectrum of weed control activity, flexibility in timing of application, low usage rates, and low mammalian toxicity (Brown, 1990; Tan et al., 2005). These herbicides inhibit the enzymatic activity of Acetohydroxyacid synthase (AHAS, EC 4.1.3.18, also known as Acetolactate synthase, ALS; Shaner et al., 1984; Ray, 1984), the first enzyme in the pathway for the synthesis of the branched chain amino acids valine, leucine, and isoleucine (Singh, 1999). This same enzyme has been shown to be the site of action for the triazolopyrimidines (TZ, Subramanian and Gerwick, 1989), pyrimidyloxybenzoates (POB, Subramanian et al., 1990), and sulfonylaminocarbonyl-triazolinones (Santel et al., 1999). Given their high effectiveness and low-toxicity, IMI and SU herbicides are favored for agricultural use. However, the ability to use both types of herbicides in a sunflower production system depends upon the availability of IMI- and SU-tolerant hybrid cultivars. To produce such tolerant cultivars, it is imperative to develop IMI or SU-tolerant plants with altered AHAS genes and enzymes. These plants have been discovered in sunflower, which permitted the development and commercialization of several herbicide-tolerant traits. Tolerance in these traits is due to a form of the AHAS large subunit enzyme (AHASL) that is less sensitive to herbicide inhibition and is conferred by a single, partially dominant nuclear gene (see Sala et al., 2012c for a review).

The first commercial herbicide tolerance trait in sunflower is known as "IMISUN" and its development started in 1996, when an IMI-tolerant wild sunflower population was discovered in Kansas, USA. Crossing these plants with cultivated sunflower lines gave rise to IMI-tolerant populations and lines (Al-Khatib et al., 1998) which were released as donor materials for developing hybrid varieties that were commercially launched in the USA, Argentina and Turkey in 2004 (Tan et al., 2005). The inheritance of IMISUN is additively controlled by two genes, where one of them is the partially dominant allele Ahasl1-1, and the other $\left(\mathrm{Imr}_{2}\right)$ is a modifier or enhancer factor (Bruniard and Miller, 2002; Miller and Al-Khatib, 2002). To produce IMISUN sunflower hybrids that express commercial tolerance levels to imidazolinone herbicides, both components need to be homozygous in the final variety (Sala et al., 2012c).

"CLPLus", another IMI tolerance trait, was developed by seed mutagenesis and is controlled by the expression of one partially dominant nuclear allele, Ahasl1-3 (Sala et al., 2008a). Biochemical studies coupled with field evaluations under many environmental conditions indicated that CLPlus provides a better level of tolerance to IMI than IMISUN (Sala et al., 2012c). Due to this high level of tolerance, only one homozygous component, namely Ahasl1-3, or the combination of both Ahasl1-1 and Ahasl1-3 alleles in the final hybrid variety, are required to achieve commercial tolerance levels to IMI (Sala et al., 2008b; Sala et al., 2012a). High level of tolerance of this trait over IMISUN sunflowers also permits to develop new herbicide formulations providing more flexible and reliable weed control (Weston et al., 2012a). The absence of genes from a wild source around Ahasl1-3 determines that the oil con- 
tents in the hybrids carrying the CLPlus trait show the same oil yield per hectare as those of their conventional counterparts (Weston et al., 2012b).

SU-tolerant sunflowers were developed from another wild sunflower population also discovered in USA (Al-Khatib et al., 1999). The tolerance allele Ahasl1-2 was introgressed into cultivated sunflower by forward crossing and selection with the herbicide tribenuron, and gave rise to the trait known as "SURES" (Miller and AlKhatib, 2004). Later, the same type of tolerance was obtained by EMS mutagenesis (Gabard and Rixheim, 2004) and was developed and commercialized under the name of "ExpressSun" (Canadian Food Inspection Agency 2008; Streit, 2012).

Based on molecular studies, Kolkman et al. (2004) identified and characterized three genes coding for the AHAS catalytic subunits in sunflower (Ahasl1, Ahasl2 and Ahasl3). Ahasl1 is the only member of this small family where all the induced and natural mutations for herbicide tolerance where described thus far in sunflower. Ahasl1-1 harbors a C-to-T mutation in codon 205 (based on Arabidopsis thaliana nomenclature) which confers a moderate tolerance to IMI and SU (Kolkman et al., 2004), Ahasl1-2 shows a C-to-T mutation in codon 197 conferring high levels of SU tolerance (Kolkman et al., 2004), and Ahasl1-3 presents a G-to-A mutation in codon 122 which confers high levels of IMI tolerance (Sala et al., 2008b).

Phenotypic identification of herbicide tolerance traits involves the spraying of herbicide onto plants grown in the field or greenhouse at early stages of development, usually V2-V4 and selection of tolerant genotypes. Screening a large number of genotypes for HT in the field is time consuming and requires a large amount of resources and space. Moreover, depending on the genetic background and type of trait, heterozygous plants for a given trait fails to survive the herbicide application. Under these circumstances, the development of efficient and reliable diagnostic bioassays or molecular markers for early screening of HT is needed. In this sense, immature-embryo (Breccia et al., 2009) and seed germination bioassays were developed for screening IMI-tolerance (Vega et al., 2009; Breccia et al., 2011; Gil et al., 2012) as well as SU-tolerance (Dimitrijević et al., 2012). Moreover, introgression of genes for herbicide resistance into high yielding sunflower germplasm can be facilitated or complemented through the use of diagnostic markers in order to unambiguously identify the different alleles involved in tolerance. The aim of this work was to present a set of allele specific molecular markers for the different herbicide resistant traits of sunflower, which can be used with various technological platforms, and applied to different objectives in the breeding program. 


\section{MATERIALS AND METHODS}

\section{Plant Materials}

Four groups of three sunflower inbred lines each; carrying different Ahasl1 alleles were used. The first group, carrying the wild-type susceptible allele ahasl1, consisted of three oilseed sunflower lines: HA89, a maintainer line released by USDA in 1971, RHA801, a restorer line released by USDA in 1974 (Roath et al., 1981) and BTK47, a Nidera's maintainer proprietary line that was described previously (Sala et al., 2008a). The second group, carrying the Ahasl1-1 allele, consisting of RHA426 and HA425, a restorer and a maintainer line, respectively, released by USDA (Al-Khatib and Miller, 2002), and IB770, a maintainer proprietary line. The third group, carrying the Ahasl 1-2 allele, consisted of three inbred lines (two maintainers and one restorer): BTSu-B1, BTSu-B2 and RTSu-R1, derived by inbreeding and selection from SURES-1 and SURES-2 (Miller and Al-Khatib, 2004). The last group, carrying the Ahasl1-3 allele, consisting of two restorers and one maintainer proprietary inbred lines: R720 (Bertero de Romano et al., 2010), BTI-R1 and BTIM1. Six $F_{1}$ hybrids, heterozygous for the Ahasl1 locus were produced crossing lines of different groups: HA89/HA425, HA89/BTSu-R1, HA89/BTI-M1, HA425/BTSu-R1, HA425/BTI-M1, BTSu-R1/BTI-M1.

\section{DNA extraction}

Fully expanded leaves were harvested and leaf tissue was frozen at $-70^{\circ} \mathrm{C}$, lyophilized, and ground to fine powder. Genomic DNA was obtained using the Qiagen 96 Plant Kit (Qiagen Inc., USA). DNA quality and quantity was determined using agarose gel electrophoresis. DNA was quantified by fluorometry using Qbit@ 173 dsDNA BR kit (Cat\# Q23850, Qiagen) and diluted to a final concentration of $50 \mathrm{ng} /$ $\mu \mathrm{l}$.

\section{Sequence alignment}

HaAHASL1 gene sequences from wild type HA89 line (GenBank accession AY541451, Kolkman et al., 2004) and herbicide tolerant lines were aligned using ClustalW software (Higgins and Sharp, 1998) and were examined for polymorphisms among them. Herbicide tolerant lines analyzed were IMISUN-1 (Ahasl1-1, GenBank accession AY541455, Kolkman et al., 2004), SURES-1 (Ahasl1-2, GenBank accession AY541453 Kolkman et al., 2004), CLHA-Plus (Ahasl1-3, GenBank accession EU342349, Sala et al., 2008c).

\section{PCR-BASED MARKERS DESIGN}

\section{SSR marker}

HaAHASL 1 gene sequence fragments were PCR-amplified in a $15 \mu \mathrm{l}$ reaction containing 1 U Taq DNA Polymerase (Biotools, Madrid), 70 ng genomic sunflower 
DNA, $25 \mu \mathrm{g}$ bovine serum albumin, with a final concentration of $100 \mu \mathrm{M}$ of each dNTP, $0.25 \mu \mathrm{M}$ of each primer p-AHAS19 (5'-CGCCGCCCTGTTCGTGAC-3') and p-AHAS18 (5'- TTCCTCCCCCGTTTCGCATTAC -3’) (Kolkman et al., 2004), 90 $\mathrm{mM}$ Tris- $\mathrm{HCl} \mathrm{pH} 8,20 \mathrm{mM}\left(\mathrm{NH}_{4}\right)_{2} \mathrm{SO}_{4}$ and $2.5 \mathrm{mM} \mathrm{MgCl} 2$. The PCR program consisted of an initial denaturation step at $94^{\circ} \mathrm{C}$ for $2 \mathrm{~min}$, followed by 40 cycles of $30 \mathrm{~s}$ at $94^{\circ} \mathrm{C}, 30 \mathrm{~s}$ at $56^{\circ} \mathrm{C}$, and $30 \mathrm{~s}$ at $72^{\circ} \mathrm{C}$, followed by a final elongation step at $72^{\circ} \mathrm{C}$ for $10 \mathrm{~min}$. Amplification products ( $3 \mu \mathrm{l}$ per lane) were separated on a standard sequencing gel containing $6 \%$ polyacrylamide, $8 \mathrm{M}$ urea, and $1 \times \mathrm{TBE}$, at $60 \mathrm{~W}$ constant power for 2 to $3 \mathrm{~h}$, and were detected by silver nitrate staining (Silver Sequence; Promega Biotech, Madison, WI). The size of each simple sequence repeat (SSR) allele was estimated using a molecular weight marker and a standard sequencing reaction in adjacent lines of the gel.

\section{CAPS marker}

The fragments obtained previously using primers p-AHAS18 and p-AHAS19 were incubated for 4 hours at $37^{\circ} \mathrm{C}$, with $2.5 \mathrm{U} \mathrm{BmgB} \mathrm{I} \mathrm{(New} \mathrm{Englands} \mathrm{Biolabs),}$ BSA $100 \mu \mathrm{g} / \mathrm{ml}$, NE Buffer $31 \times(100 \mathrm{mM} \mathrm{NaCl}, 50 \mathrm{mM}$ Tris $\mathrm{HCl}, 10 \mathrm{mM} \mathrm{MgCl} 2,1$ $\mathrm{mM}$ ditiotreitol $\mathrm{pH}$ 7,9) in $10 \mu \mathrm{l}$. Restriction fragments were separated on a standard sequencing gel as described above or in metaphor agarose gels $4 \%$.

\section{SNP marker}

Genomic DNA was PCR-amplified using the primer combination p-AHASNidF (5'-TGTTCTCTCCGACTCCAAA-3') and p-AHAS122TMU (5'-TGGTGGATCTCCATTGAGTT-3') for the detection of Ahasl1-3 allele; and p-AHASNidF (5'-TGTTCTCTCCGACTCCAAA-3') and p-AHAS122TWT (5'-TGGTGGATCTCCATTGAGTC-3') for the detection of the remaining alleles. The reaction mix was as follows: 1 U Taq DNA Polimerase (Biotools, Madrid), 70 ng genomic sunflower DNA, $25 \mu \mathrm{g}$ BSA, and have a final concentration of $100 \mu \mathrm{M}$ of each dNTP, $0.25 \mu \mathrm{M}$ of each primer p-AHAS NIDF/AHAS122TWT or p-AHAS NIDF/ AHAS122TMU, $90 \mathrm{mM}$ Tris $\mathrm{HCl} \mathrm{pH} \mathrm{8,} 20 \mathrm{mM}\left(\mathrm{NH}_{4}\right)_{2} \mathrm{SO}_{4}$ and $2.5 \mathrm{mM} \mathrm{MgCl}_{2}$. The PCR program consists in an initial denaturation step of $94^{\circ} \mathrm{C}$ for $2 \mathrm{~min}$, followed by 45 cycles of $30 \mathrm{~s}$ at $94^{\circ} \mathrm{C}, 30$ $\mathrm{s}$ at $55^{\circ} \mathrm{C}$ and $30 \mathrm{~s}$ at $72^{\circ} \mathrm{C}$, followed by a final elongation step at $72^{\circ} \mathrm{C}$ for $10 \mathrm{~min}$. Amplification products ( $3 \mu \mathrm{l}$ per lane) were separated on a standard sequencing gel as described before or in metaphor agarose gels $4 \%$.

\section{RESULTS}

\section{Differences among Ahasl1 alleles sequences}

The Ahasl1 gene sequences from wild-type and herbicide resistance lines showed differences for some single nucleotide polymorphisms and an [ACC]n repeat comprising four haplotypes. A partial alignment is shown in Figure 1. The Ahasl1-1 allele, as identified from HA425, RHA426 and IB770 Ahasl1 gene 
sequence, harbored an alanine (GCG) to valine (GTG) mutation in codon 205 (relative to the Arabidopsis thaliana AHAS sequence), whereas the Ahasl1-2 allele, as identified from BTSu-B1, BTSu-B2 and RTSu-R1 Ahasl1 gene sequence, carried a proline (CCC) to leucine (CTC) mutation in codon 197. The Ahasl1-3 allele, as represented in R720, BTI-M1 and BTI-R1, harbored a threonine codon (ACG) at position 122, whereas the herbicide-susceptible enzyme from BTK47 has an alanine residue (GCG) at this position.

\begin{tabular}{|c|c|c|}
\hline $\begin{array}{l}\text { Ahasl1-3 } \\
\text { ahasl1 }\end{array}$ & 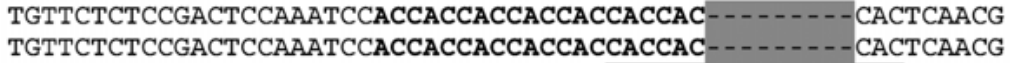 & $\begin{array}{l}51 \\
51\end{array}$ \\
\hline Ahasl1-1 & TGTTCTCTCCGACTCCAAATCCACCACCACCACCAC- & 42 \\
\hline \multirow[t]{2}{*}{ Ahas11-2 } & TGTTCTCTCCGACTCCAAATCCACCACCACCACCACCACCACCACCACCACCACTCAACC & 60 \\
\hline & 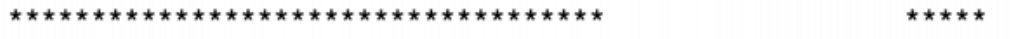 & \\
\hline $11-3$ & ACCGTTACCGGTGCAGCCTTTTGTCTCCCGTTACGCGCCAGATCAACCGAGAAAAGGCGC & 111 \\
\hline ahas11 & ACCGTTACCGGTGCAGCCTTTTGTCTCCCGTTACGCGCCAGATCAACCGAGAAAAGGCGC & 111 \\
\hline s11-1 & ACCGTTACAGGCGCAGCCTTTTGTCTCCCGTTACGCGCCAGATCAACCGAGAAAAGGCGC & 102 \\
\hline \multirow[t]{2}{*}{ Ahas11-2 } & ACCGTTACAGGCGCAGCCTTTTGTCTCCCGTTACGCGCCTGATCAACCGAGAAAAGGCGC & 120 \\
\hline & 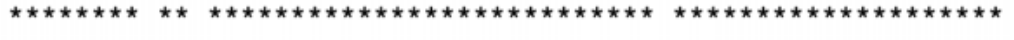 & \\
\hline Ahas11-3 & AGACGTGTTGGTGGAAGCTCTGGAACGGGAAGGTGTCACCGACGTCTTCGCCTACCCCGG & 171 \\
\hline ahas 11 & AGACGTGTTGGTGGAAGCTCTGGAACGGGAAGGTGTCACCGACGTCTTCGCCTACCCCGG & 171 \\
\hline Ahas11-1 & AGACGTGTTGGTGGAAGCTCTAGAACGGGAAGGTGTCACCGACGTCTTCGCCTACCCCGG & 162 \\
\hline $11-2$ & 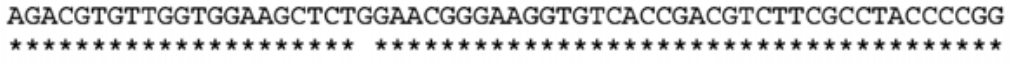 & 180 \\
\hline as $11-3$ & CGTCAATGGAGATCCACCA 195 & \\
\hline $1 s 11$ & CGGdGCGTCAATGGAGATCCACCA 195 & \\
\hline Ahas11-1 & CGGdGCGTCAATGGAGATCCACCA 186 & \\
\hline Ahas11-2 & 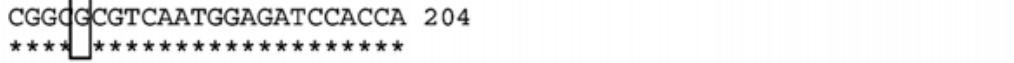 & \\
\hline
\end{tabular}

Figure 1. Partial nucleotide sequences alignment of HaAhASL1 for four different alleles: ahasl1 (susceptible), Ahasl1-1 (IMISUN), Ahasl1-2 (SURES), and Ahasl1-3 (CLPLUS). The poly-Thr $(A C C)_{n}$ repeat and INDELs in the nucleotide sequence of the putative transit peptide of AHASL1 protein are shown in bold type and grey shaded, respectively. The position of the A122T single nucleotide polymorphism is also shown (marked out in a box). Numbers at the end of the sequences indicate the expected size of each PCR fragment.

The poly-Thr $(\mathrm{ACC})_{\mathrm{n}}$ repeat in the putative transit peptide of HaAHASL1, determines a variation in size for the alleles Ahasl1-1 and Ahasl1-2 with respect to the wild-type allele. Ahasl1-3, on the other hand, does not show a variation in size with respect to the wild-type allele. Differences observed in the four Ahasl1 sequences analyzed allowed developing three types of PCR-based markers, which are described below.

\section{SSR marker}

The presence of an ACC repetition pattern in the nucleotide sequence of the putative transit peptide of the AHASL protein sequence permitted to develop an SSR marker. Primers p-AHAS18 and p-AHAS19 were developed by Kolkman et al. (2004) in order to take advantage of the size differences obtained in the different 
resistant alleles. This marker was previously used to discriminate plants carrying the Ahasl1-1 allele from Ahasl1-3 allele and the heterozygous combination of both (Sala et al., 2008a). As expected from sequence analysis, this marker yields a $312 \mathrm{bp}$ band for RHA426, HA425 and IB770 (Ahasl1-1 allele), a 321 pb PCR fragment for R720, BTI-M1, BTI-R1, BTK 47, RHA801 and HA89 (Ahasl1-3 and ahasl1 alleles), and a 330bp band for BTSu-B1, BTSu-B2 and BTSu-R1 (Ahasl1-2 allele).

The size of the bands obtained from the analyzed hybrids were: $321 / 312 \mathrm{bp}$ for HA89/HA425, 321/330bp for HA89/BTSu-R1, 321bp for HA89/BTI-M1, 312/330bp for HA425/BTSu-R1, 312/321bp for HA425/BTI-M1 and 330bp/312bp for BTSuR1/BTI-M1. Because of its codominant nature, this marker is able to identify the alleles carried by heterozygous hybrids (Figure 2).

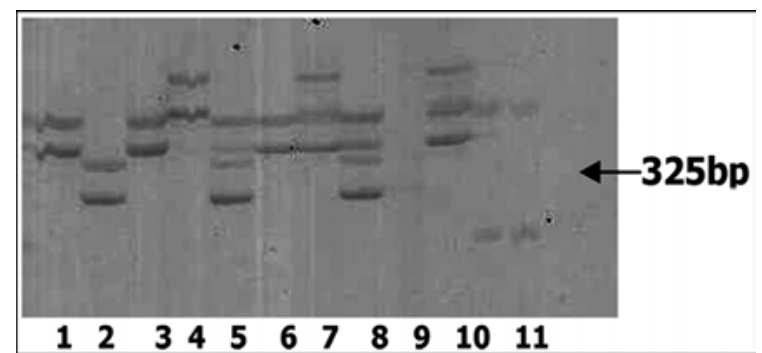

Figure 2. SSR marker analysis. The SSR amplification reaction was carried out for the homozygous genotypes HA89 (ahasl1/ahasl1), HA425 (Ahasl1-1/ Ahasl1-1), BTSu-R1 (Ahasl1-2/ Ahasl1-2), and BTI-M1 (Ahasl1-3/Ahasl1-3), and for the $F_{1}$ hybrids carrying different allelic combinations at this locus. Lane 1: HA89, lane 2: HA425, lane 3: BTI-M1, lane 4: BTSU-R1, lane 5: HA89/HA425, lane 6: HA89/ BTI-M1, lane 7: HA89/BTSu-R1, lane 8: HA425/BTI-M1, lane 9: negative control (water), lane 10: BTSU-R1/BTI-M1, lane 11: molecular weight marker 25bp.

No difference in fragment size were observed for lines carrying ahasl1 and Ahasl1-3 allele since both of them harbor the same number of (ACC) repeats in the nucleotide sequence of the putative transit peptide. In this case it was necessary to use another type of marker or phenotypic assays in order to identify these alleles or their combination.

\section{CAPS marker}

The sequence obtained from the lines carrying Ahasl1-3 (CLPlus) presents a single nucleotide polymorphism when compared with the sequence obtained from the line carrying the ahasl1 allele (wild type). This polymorphism is the responsible for the A to T aminoacidic change in position 122, the functional SNP that produce the high level of IMI tolerance in the CLPlus lines (Sala et al., 2012f). This polymorphism could be detected by the use of the $B m g B$ I restriction enzyme, and it was used to develop a CAPS marker. By this way, two restriction fragments $(183+138$ $\mathrm{bp)}$ were obtained for the wild type allele ahasl1 present in the lines BTK 47, RHA801 and HA89; whereas three different restriction fragments $(183+77+62$ 
bp) were observed for the Ahasl1-3 allele present in the CLPlus lines R720, BTI-M1 and BTI-R1 (Figure 3).

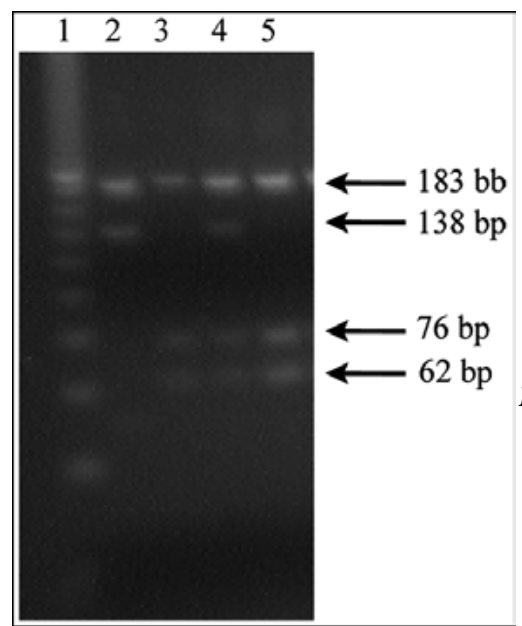

Figure 3. CAPS marker analysis. The restriction reaction was carried out for the genotypes ahasl1/ahasl1, Ahasl1-3/Ahasl1-3 and a $F_{1}$ hybrid carrying ahasll and Ahasl1-3 in heterozygous condition. Lane 1: molecular weight marker 25bp, lane 2: HA89, lane 3: BTI-M1, lane 4: HA89/BTI-M1, lane 5: BTI-M1.

\section{SNP marker}

Primers were designed in order to make use of the characteristic SNP present in the sequence of the Ahasl1-3 allele, in addition to the previously mentioned unique ACC repetition pattern for each Ahasl1 allele. Both features were used to develop two SNPs assays, that when used in combination, permits to discriminate all the previously described alleles and, hence, the zygosity of the locus Ahasl1.

As expected from sequences analysis, the combination of p-AHASNidF with pAHAS122TWT yields a 195 bp band for the herbicide susceptible lines BTK 47, RHA801 and HA89 (ahasl1 allele), a 186 bp band for lines RHA426, HA425 and IB770 (Ahasl1-1 allele, IMISUN trait), a 204bp band for lines BTSu-B1, BTSu-B2 and BTSu-R1 (Ahasl1-2 allele, SURES trait) and produces no amplification product for the lines R720, BTI-M1, BTI-R1 (Ahasl1-3 allele, CLPlus trait). On the other hand, the combination of p-AHASNidF with pAHAS122TMU only produce an amplified fragment of $195 \mathrm{bp}$ for the lines R720, BTI-M1, BTI-R1, while the other lines under study yields no fragment for this primer combination (Figure 4).

The combination of p-AHASNidF with pAHAS122TWT evaluated in heterozygous $\mathrm{F}_{1}$ hybrids yielded two fragments of 195 and $186 \mathrm{bp}$ for the hybrid HA89/ HA425, two bands of 195 and 204 bp for the $F_{1}$ hybrid HA89/BTSu-R1, only one band of $195 \mathrm{bp}$ for the combination HA89/BTI-M1, two bands of 186 and $204 \mathrm{bp}$ for the $\mathrm{F}_{1}$ hybrid HA425/BTSu-R1, only one fragment of $186 \mathrm{bp}$ was observed for HA425/BTI-M1 and also a single band of $204 \mathrm{bp}$ was obtained for the $\mathrm{F}_{1}$ hybrid combination BTSu-R1/BTI-M1. For the primer combination p-AHASNidF and pAHAS122TMU a single band of $195 \mathrm{bp}$ was observed for the hybrids HA89/BTIM1, HA425/BTI-M1 and BTSu-R1/BTI-M1. The other three hybrids under analysis 
did not produce any amplification product after assayed with this combination of primers.

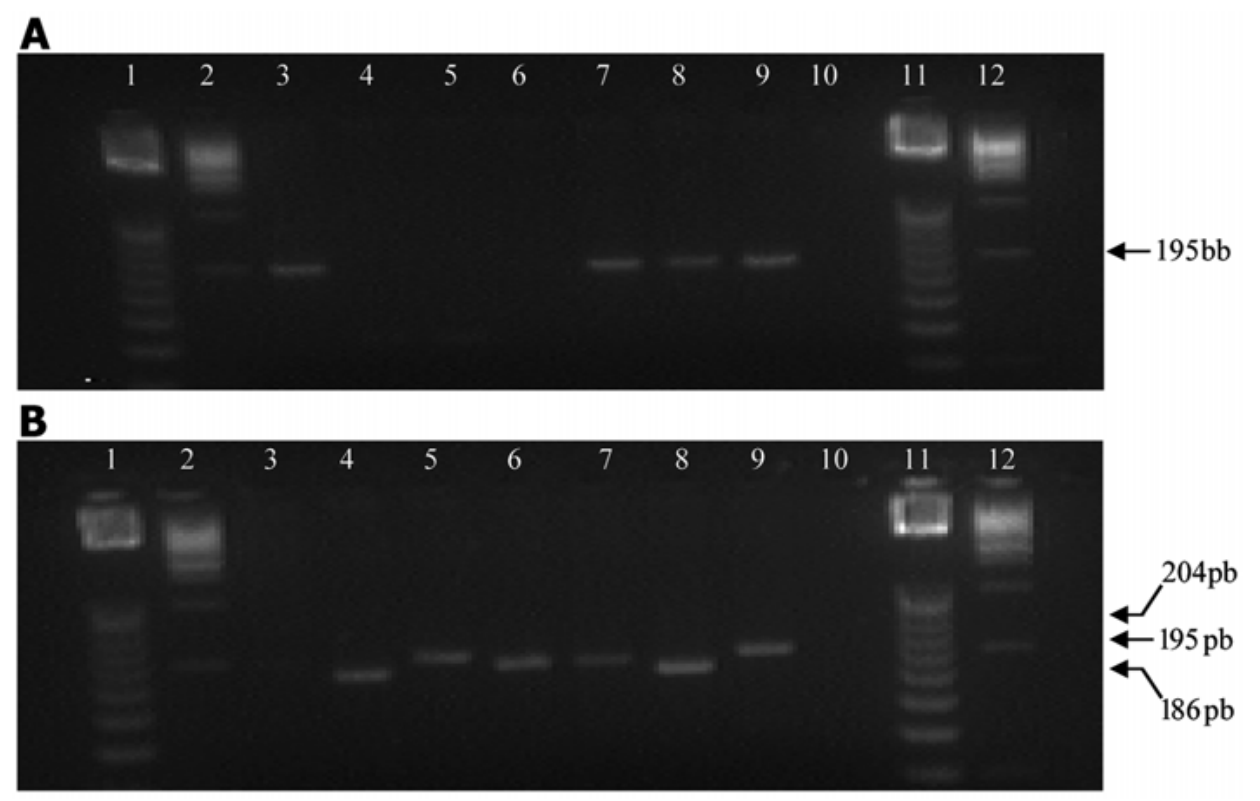

Figure 4. SNP marker analysis. A) Primer combination p-AHASNidF/p-AHAS122TMu. B) Primer combination p-AHASNidF/ p-AHAS122TWT. Lane 1: molecular weight marker 25bp , lane 2: molecular weight marker $1 \mathrm{~Kb}$, lane 3: BTI-M1, lane 4: HA425, lane 5: BTSU-B1, lane 6: HA89, lane 7: BTI-M1/HA89, lane 8: BTI-M1/ HA425, lane 9: BTI-M1/BtSu-B1, lane 10: negative control (water), lane 11: molecular weight marker $25 \mathrm{bp}$, lane 12: molecular weight marker $1 \mathrm{~Kb}$.

\section{DISCUSSION}

Advantages of marker assisted selection were well demonstrated through a lot of examples in most of the crops and for many different traits (Sala et al., 2010; Mohan et al., 1997; Xu and Crouch, 2008; Francia et al., 2005). In sunflower, marker assisted selection was used mainly for the selection of disease resistant genes (see, for example, Paniego et al., 2007, 2012; Liu and Jan, 2012).

Polymorphisms detected for the different alleles at the Ahasl1 locus allow the design of different types of markers, useful to efficiently assist breeding programs aimed to develop herbicide resistant sunflower hybrids. The developed markers, which differ in the easiness of implementation and in their processivity, could be adapted to different type of breeding programs depending on the aims pursued and the available technological platforms.

However, the use of molecular markers for herbicide tolerance selection into a breeding program is not a common application due to the apparent easiness of phe- 
notypic selection for this kind of trait. Up to now, herbicide tolerance in crops are mostly governed by only one gene, and most of them are dominant transgenic or mutant genes (Walker et al., 2006; Sebastian et al., 1989; Newhouse et al., 1991), so phenotypic selection, based on plant injury after herbicide treatments, seems to be the simplest way to select for these traits (see Škorić, 2012 for a discussion about the development of herbicide-resistant sunflower hybrids).

Plant injury in HT crops consists of several symptoms such as chlorosis, stunting, yellowing, decreased biomass production and yield loss. The plant injury phenotype can be attributed to the interaction between genotype and environment. The environmental component for herbicide tolerance is a sum of abiotic and biotic factors coupled with the effect of the type of herbicide and application parameters such as herbicide rates, surfactants and application timing (see for example, Frihauf et al., 2005; Geier et al., 2004; Stougaard et al., 2004). Any change in these application parameters can determine a change in the plant injury phenotype leading to misclassification of the actual genotype of the assayed plants. On the other hand, the genotypic factor is the sum of the HT gene effect (the additive effect of the allele/s present at the Ahasl1 locus) plus the effect of the remaining genetic background (Imr2, enhancer factor, or more precisely, the mechanisms of the plant to detoxify xenobiotics, see Sala et al., 2012e), and the interaction between the two. When the effect of the HT gene is modest (IMISUN sunflowers, for example) the nontarget mechanism of tolerance and the interaction between the two become more important in explaining the tolerance (Sala et al., 2008b, 2012d). For these reasons, in many instances (for example, a $\mathrm{BC}_{1} \mathrm{~F}_{1}$ population grown under greenhouse conditions and segregating for Ahasl1-1 without Imr2) the applied dose of herbicide can kill or severely injure almost all the plants so that their recovery from the herbicide application is almost impossible. In other cases (for example, a population fixed for Imr2 and segregating for Ahasl1-1 and Ahasl1-3) it is not easy to determine the genotype of the plant through its phenotype since all the plants will show a highly resistant phenotype. In these cases, marker assisted selection allow to select plants without the drawbacks of herbicide injury or the limitations to determine the actual genotype of a plant through its phenotype for herbicide injury. In fact, both examples can be assessed easily with the SSR marker described in this work.

Marker assisted selection for tolerance to AHAS inhibitor herbicides can greatly simplify the breeding process along the several steps needed to obtain a resistant sunflower inbred line. SSR markers described in this work allow differentiating SURES from IMISUN resistant plants and also permit to distinguish both traits from susceptible wild type, and CLPlus resistant plants. The CAPS marker is useful to assist the conversion of conventional sunflower lines to CLPlus resistant lines by a marker assisted backcross procedure without using any herbicide related phenotypic test. Also, the codominant nature of this marker makes it useful to detect homozygous plants during the last steps of the conversion process $\left(\mathrm{BC}_{2} \mathrm{~F}_{2}\right.$ or $\mathrm{BC}_{3} \mathrm{~F}_{2}$ ), which permits to save one generation of progeny testing to detect homozy- 
gotes. The SNPs markers developed also can be used for line conversions, rapid sterilization of maintainer lines and characterization of the resistant gene present in lines extracted from populations segregating for two or more resistant traits. The main advantage of this last system is that it can be easily modified to increase its processivity toward a high-throughput platform. Because of the dominant nature of the SNP markers they can also be applied for checking seed purity of any particular resistant line in order to assure it carries the correct trait (IMISUN, SURES o CLPlus) in any specified level (99\% for example). In fact, these SNPs are being applied in a Real-Time assays in order to quantify specific amounts of off-types for a given herbicide resistant trait (Sensolini et al., 2012).

\section{CONCLUSSION}

Ahasl1 is a sunflower multiallelic locus which can carry different alleles for tolerance to AHAS inhibitor herbicides. Each one of the alleles at this locus controls the tolerance to one or more herbicides and, for this reason; each allele is the base of a technology of weed control in this crop. Hence, up to the present there exist three herbicide tolerance traits in sunflower, known as IMISUN, SURES, and CLPlus, which are determined by the expression of the alleles Ahasl1-1, Ahasl1-2 and Ahasl1-3, respectively. Besides the target-site mechanism of resistance conferred by the mutation in Ahasl1, IMISUN and SURES technologies also need a non-target mechanism of detoxification controlled by a completely different genetic system. Up to now phenotypic selection, based on plant injury after herbicide treatments, seems to be the simplest way to select for these traits. However, introgression of Ahasl1 alleles into high yielding sunflower germplasm should be complemented through the use of molecular markers in order to unambiguously identify the different alleles involved in tolerance and to speed up the selection process during line conversions by means of marker assisted backcross selection procedures. In these cases, marker assisted selection allow to select plants without the drawbacks of herbicide injury or the limitations to determine the actual genotype of a plant through its phenotype for herbicide injury. For these reasons, the aim of this work was to present a set of allele specific molecular markers for the different herbicide resistant traits of sunflower, which can be used with various technological platforms, and applied to different objectives in the breeding program. The Ahasl1 gene sequences from lines carrying different alleles for susceptibility or resistance showed single nucleotide polymorphisms and length variations for a simple sequence repeat. These differences were utilized to develop three types of PCR markers (SSRs, CAPS and SNPs) which allow the precise identification of each allele at the Ahasl1 locus. This information not only can be used for breeding purposes but also for the determination of off types and trait purity assessment of commercial seed lots. 


\section{REFERENCES}

Al-Khatib, K., Baumgartner, J.R., Currie, R.S., 1999. Survey of common sunflower (Helianthus annuus) resistance to ALS-inhibiting herbicides in northeast Kansas. In: Proc $21^{\text {th }}$ Sunflower Res. Workshop. National Sunflower Association, Bismark, N.D., pp. 210-215.

Al-Khatib, K., Baumgartner, J.R., Peterson, D.E., Currie, R.S., 1998. Imazethapyr resistance in common sunflower (Helianthus annuus). Weed Science 46: 403-407.

Al-Khatib, K., Miller, J.F., 2000. Registration of four genetic stocks of sunflower resistant to imidazolinone herbicides. Crop Science 40: 869-870.

Bernasconi, P., Woodworth, A.R., Rosen, B.A., Subramanian, M.V., Siehl, D.L., 1995. A naturally occurring point mutation confers broad range tolerance to herbicides that target acetolactate synthase. J. Biol. Chem. 270: 17381-17385.

Bertero de Romano, A., Romano, C., Bulos, M., Altieri, E., Sala, C.A., 2010. A new gene for resistance to downy mildew in sunflower. In: Proceedings of the International Symposium Sunflower Breeding on Resistance to Diseases, Krasnodar, Russia, June 23-24, 2010, pp. 140-146.

Breccia, G., Vega, T., Nestares, G., Mayor, M.L., Zorzoli, R. and Picardi, L., 2009. Inmature embryo culture for early screening of imidazolinone resistant sunflower. International Journal of Plant Breeding 3: 37-40.

Breccia, G., Vega, T., Nestares, G., Mayor, M.L., Zorzoli, R. and Picardi, L., 2011. Rapid test for detection of imidazolinone resistance in sunflower (Helianthus annuus L.). Plant Breeding 130: 109-113.

Bruniard, J.M., Miller, J.F., 2001. Inheritance of imidazolinone herbicide resistance in sunflower. Helia 24(35): 11-16.

Canadian Food Inspection Agency, 2008. Decision Document DD2008-69 Determination of the Safety of Pioneer Hi-Bred Production Ltd.'s Sulfonylurea-Tolerant ExpressSun ${ }^{\mathrm{TM}}$ Sunflower (Helianthus annuus L.) SU7. http://www.inspection.gc.ca/english/plaveg/bio/dd/ dd0869e.shtml. Accesed 14 April, 2011.

Collard, B.C.Y., Mackill, D.J., 2008. Marker-assisted selection: an approach for precision plant breeding in the twenty-first century. Philosophical Transactions Royal Society, Serie B 363: 557-572.

Dimitrijević, A., Imerovski, I., Miladinović, D., Jocić, S., Malidža, G., Šurlan-Momirović, G. and Miklič, V., 2012. Laboratory method for detection of tribenuron-methyl resistant sunflower (Helianthus annuus L.). In: Proc. $18^{\text {th }}$ Sunflower Int. Conf., Mar del Plata-Balcarce, Argentina, pp. 518-523.

Francia, E., Tacconi, G., Crosatti, C., Barabaschi, D., Bulgarelli, D., Dall'Aglio, E., Valè, G., 2005. Marker assisted selection in crop plants. Plant Cell Tissue and Organ Culture 82: 317 342.

Frihauf, J.C., Miller, S.D. and Alford, C.M., 2005. Imazamox rates, timings, and adjuvants affect imidazolinone-tolerant winter wheat cultivars. Weed Technology 19: 599-607.

Gabard, J.M., Huby, J.P., 2002. Sulfonylurea-tolerant sunflower line M7. United States Patent 6822146, filled 28 August 2002, Issued 23 November 2004.

Geier, P.W., Stahlman, P.W., White, A.D., Miller, S.D., Alford, C.M. and Lyon, D.J., 2004. Imazamox for winter annual grass control in imidazolinone-tolerant winter wheat. Weed Technology 18: 924-930.

Gil, M., Breccia, G., Vega, T., Bulos, M., Sala, C.A. and Nestares, G., 2012. Soil-less bioassay for the identification of plants carrying different imidazolinone-tolerant alleles in sunflower. In: Proc. $18^{\text {th }}$ Int. Sunflower Conf., Mar del Plata-Balcarce, Argentina, pp. 524-529.

Higgins, D.G., Sharp, P.M., 1988. CLUSTAL: a package for performing multiple sequence alignment on a microcomputer. Gene 73: 237-244.

Kolkman, J.M., Slabaugh, M.B., Bruniard, J.M., Beny, S., Bushman, B.S., Olungu, C., Maes, N., Abratti, G., Zambelli, A., Miller, J.F., Leon, A., Knapp, S.J., 2004. Acetohydroxyacid synthase mutations conferring resistance to imidazolinone or sulfonylurea herbicides in sunflower. Theoretical and Applied Genetics 109: 1147-1159.

Lawson, W.R., Goulter, K.C., Henry, R.J., Kong, G.A., Kochman, J.K., 1998. Marker assisted selection for two rust resistance genes in sunflower. Molecular Breeding 4: 227-234.

Liu, Z., Jan, C.C., 2012. Molecular techniques for sunflower breeding. In: Sunflower Genetics and Breeding. International Monography. Serbian Academy of Sciences and Arts, Branch in Novi Sad, Chapter 2, pp. 431-475. 
Miller, J.F., Al-Khatib, K., 2002. Registration of imidazolinone herbicide-resistant sunflower maintainer (HA425) and fertility restorer (RHA426 and RHA427) germplasms. Crop Science 42: 988-989.

Miller, J.F., Al-Khatib, K., 2004. Registration of two oilseed sunflower genetic stocks, SURES1 and SURES-2, resistant to tribenuron herbicide. Crop Science 44: 1037-1038.

Mohan, M., Nair, S., Bhagwat, A., Krishna, T.G., Yano, M., Bhatia, C.R., Sasaki, T., 1997. Genome mapping, molecular markers and marker-assisted selection in crop plants. Molecular Breeding 3: 87-103.

Newhouse, K., Singh, B.K., Shaner, D., Stidham, M., 1991. Mutations in corn (Zea mays L.) conferring resistance to imidazolinone herbicides. Theoretical and Applied Genetics 83: 65-70.

Paniego, N., Heinz, R., Fernandez, P., Talia, P., Nishinakamasu, V., Hopp, H.E., 2007. Sunflower. In: Kole, C. (ed.) Genome Mapping and Molecular Breeding in Plants, Volume 2 Oilseeds, Springer-Verlag Berlin, Heidelberg, pp. 153-177.

Paniego, N., Bazzalo, M.E., Bulos, M., Lia, V., Fusari, C., Alvarez, D., Altieri, E., Ramos, M.L., Galella, M.T., Kaspar, M., 2012. Genomics, mapping and marker assisted selection strategies for disease resistance. In: Proc $18^{\text {th }}$ Int. Sunflower Conf., Mar del Plata, Argentina, pp. 44-50.

Ray, T.B., 1984. Site of action of chlorsulfuron. Inhibition of valine and isoleucine biosynthesis in plants. Plant Physiology 100: 882-886.

Roath, W.W., Miller, J.F., Gulya, T.J., 1981. Registration of RHA801 Sunflower Germplasm. Crop Science, Reg. No. GP 5.

Saari, L.L., Cotterman, J.C., Thill, D.C., 1994. Resistance to acetolactate synthase inhibiting herbicides. In: Powles S.B., Holtum, J.A.M. (eds) Herbicide resistance in plants: biology and biochemistry. Lewis Publishers, Boca Raton, FL, USA, pp. 83-139.

Sala, C.A., Bulos, M., Fresco, A., Altieri, E., 2010. Marcadores moleculares y mejoramiento genético de cultivos. In: Levitus, G., Echenique, V., Rubinstein, C., Hopp, E., Mroginski, L. (eds), Biotecnología y Mejoramiento Vegetal II. Ediciones Instituto Nacional de Tecnología Agropecuaria, Buenos Aires, pp. 325-338.

Sala, C.A., Bulos, M., Echarte, A.M., 2008a. Genetic analysis of an induced mutation conferring imidazolinone resistance in sunflower. Crop Science 48: 1817-1822.

Sala, C.A., Bulos, M., Echarte, A.M., Whitt, S., Budziszewski, G., Howie, W., Singh, B., Weston, B., 2008b. Development of CLHA-Plus: a novel herbicide tolerance trait in sunflower conferring superior imidazolinone tolerance and ease of breeding. In: Proc $17^{\text {th }}$ Int. Sunflower Conf., Córdoba, España, pp. 489-494.

Sala, C.A., Bulos, M., Echarte, A.M., Whitt, S.R., Ascenzi, R., 2008c. Molecular and biochemical characterization of an induced mutation conferring imidazolinone resistance in sunflower. Theoretical and Applied Genetics 108: 115-112.

Sala, C.A. and Bulos, M., 2012. Use of imidazolinone tolerance to produce male-sterile testers in sunflower breeding programs. In: Proc $18^{\text {th }}$ Int. Sunflower Conf., Mar del PlataBalcarce, Argentina, pp. 706-711.

Sala, C.A., Bulos, M., Altieri, E., Weston, B., 2012a. Response to imazapyr and dominance relationships of two imidazolinone-tolerant alleles at the Ahasl1 locus of sunflower. Theoretical and Applied Genetics 124: 385-396.

Sala, C.A., Bulos, M., Altieri, E. and Ramos, M.L., 2012b. Sunflower: improving crop productivity and abiotic stress tolerance. In: N. Tuteja, S. Gill, A.F. Tubercio, R. Tuteja (Eds.) Improving crop resistance to abiotic stress. Wiley-Blackwell Wiley-VCH Verlag GmbH \& Co., pp. 1205-1249.

Sala, C.A., Bulos, M., Altieri, E., Ramos, M.L., 2012c. Genetics and breeding of herbicide tolerance in sunflower. Helia 35: 57-70.

Sala, C.A., Bulos, M., Altieri, E., Ramos, M.L., 2012d. Root biomass response to foliar application of imazapyr for two imidazolinone tolerant alleles of sunflower (Helianthus annuus L.). Breeding Science 62: 235-240.

Sala, C.A., Bulos, M., Altieri, E., Ramos, M.L., 2012e. Imisun tolerance is the result of the interaction between target and non-target tolerance mechanisms. In: Proc $18^{\text {th }}$ Int. Sunflower Conf., Mar del Plata-Balcarce, Argentina, pp. 551-556.

Sala, C.A., Bulos, M., Weston, B., 2012f. Relative tolerance, stability, and reliability of two herbicide tolerance traits in sunflower. In: Proc $18^{\text {th }}$ Int. Sunflower Conf., Mar del PlataBalcarce, Argentina, pp. 545-550. 
Santel, H.J., Bowden, B.A., Sorensen, V.M., Mueller, K.H., Reynolds, J., 1999. Flucarbazonesodium-a new herbicide for grass control in wheat. Proc. West Soc. Weed Science 52: 124125.

Sensolini, R., Ramos, M.L., Bulos, M., Altieri, E. and Sala, C.A., 2012. Tecnología de detección de contaminantes para un locus de tolerancia a imidazolinonas en girasol. Journal of Basic \& Applied Genetics XXIII: 274 (abstract).

Shaner, D.L., Anderson, P.L., Stidham, M.A., 1984. Imidazolinones: potent inhibitors of acetohydroxyacid synthase. Plant Physiology 76: 545-546.

Shaner, D.L., Singh, B.K., 1997. Acetohydroxyacid synthase inhibitors. In: Roe, R.M., Burton, J.D., Kuhr, R.J., (eds.) Herbicide activity: toxicology, biochemistry and molecular biology. IOS Press, Amsterdam, pp. 69-110.

Škorić, D., 2012. Sunflower breeding. In: Sunflower Genetics and Breeding. International Monography. Serbian Academy of Sciences and Arts, Branch in Novi Sad, Chapter 2, pp.165-354.

Stougaard, R.N., Mallory-Smith, C.A. and Mickelson, J.A., 2004. Downy brome (Bromus tectorum) response to imazamox rate and application timing in herbicide-resistant winter wheat. Weed Technology 18: 1043-1048.

Streit, L., 2012. DuPont ${ }^{\mathrm{TM}}$ ExpressSun ${ }^{\mathrm{TM}}$ Herbicide Technology in Sunflower. In: Proc. $18^{\text {th }}$ Int. Sunflower Conf., Mar del Plata-Balcarce, Argentina, pp. 143-149.

Subramanian, M.V., Gerwick, B.C., 1989. Inhibition of Acetolactate Synthase by Triazolopyrimidines. In: Whitaker, J.R. (ed.) Biocatalysis in Agricultural Biotechnology, ACS Symposium Series Vol. 389, American Chemical Society, Washington, DC, pp. 277-288.

Tan, S., Evans, R.R., Dahmer, M.L., Singh, B.K. and Shaner, D.L., 2005. Imidazolinone tolerant crops: history, current status and future. Pesticide Managment Science 61: 246-257.

Vega, T., Breccia, G., Nestares, G., Mayor, M.L., Zorzoli, R. and Picardi, L., 2009. Soil-less bioassays for early screening for resistance to imazapyr in sunflower (Helianthus annuus L.). Pest Management Science 65: 991-995.

Walker, D., Walker, R., Wood, A.K., Talevera, E.D., Fernandez, M.E., Rowan, F.E., Moots, G.B., Leitz, C.K., Owen, R.A., Baxter, P.A., Head, W.E., Boerma, J.L., Roger, H., 2006. Gametic selection by glyphosate in soybean plants hemizygous for the CP4 EPSPS transgene. Crop Science 46: 30-35.

Weston, B., McNevin, G. and Carlson, D., 2012a. Clearfield ${ }^{\circledR}$ Plus Technology in Sunflowers. In: Proc. XVIII Sunflower Conf., Mar del Plata-Balcarce, Argentina, pp. 149-154.

Weston, B., Pfenning, M., Perez-Brea, J., Tan, S., McNevin, G., Carlson, D., de Romano, A., Romano, C., Bulos, M. and Sala, C.A., 2012b. Yield and oil improvements in Clearfield plus sunflowers. In: Proc. $18^{\text {th }}$ Sunflower Conf., Mar del Plata-Balcarce, Argentina, pp. 557-562.

$\mathrm{Xu}$ Y., Crouch, J.H., 2008. Marker-assisted selection in plant breeding: from publications to practice. Crop Science 48: 391-407. 


\title{
SELECCIÓN ASISTIDA POR MARCADORES PARA RESISTENCIA A HERBICIDAS EN GIRASOL
}

\author{
RESUMEN
}

IMISUN, SURES, y CLPlus son tres caracteres que confieren resistencia a herbicidas en el girasol (Helianthus annuus L.), los cuales están determinados por la expresión de diferentes alelos del mismo locus, Ahasl1. La introgresión de estos genes en el germoplasma de girasol de alto rendimiento debería estar complementada con el uso de marcadores moleculares con el objeto de identificar correctamente los diferentes alelos involucrados en la tolerancia. El objetivo de este trabajo es presentar un conjunto de marcadores moleculares específicos de alelo para los diferentes rasgos de resistencia a herbicidas en el girasol, los que puedan utilizarse con diversas plataformas tecnológicas y ser aplicados a diferentes objetivos en un programa de mejoramiento genético. Las diferencias observadas para las secuencias Ahasl1 de las fuentes que llevan los alelos para resistencia y las líneas de tipo silvestre permitieron el desarrollo de tres tipos de marcadores diferentes basados en PCR (SSRs, CAPs y SNPs) que permiten identificarlas. Se discute la utilidad de estos marcadores y la estrategia de su implementación para la obtención de líneas resistentes a herbicidas.

\section{SELECTION ASSISTÉE PAR MARQUEURS DE L'HERBICIDE RÉSISTANCE EN TOURNESOL}

\author{
RÉSUMÉ
}

IMISUN, SURES, et CLPlus sont trois different caractères confèrent une résistance aux herbicides du tournesol (Helianthus annuus L.), Les memes sont déterminées par l'expression des différents allèles du même locus, Ahasl1. L'introgression de ces gènes dans le matériel génétique de tournesol de haute performance devrait être complétée par l'utilisation de marqueurs moléculaires afin d'identifier correctement les différents allèles impliqués dans la tolérance. Le but de cet article est de présenter un ensemble de marqueurs moléculaires spécifiques d'allèles pour les différents traits de résistance aux herbicides du tournesol, qui peuvent être utilisés avec différentes platesformes technologiques et d'être appliquées à différentes cibles dans le programme d'amélioration. Les séquences de gènes Ahasl1 de lignes portent des allèles de susceptibilité ou de résistance montré polymorphismes nucléotidiques simples et les variations de longueur pour une répétition de séquence simple. Ceux-ci ont été differences qui servent à établir trois types de marqueurs PCR (SSR, CAPS et SNP) qui permettent l'identification de chaque allèle au locus Ahasl1. L'utilité de ces marqueurs par rapport à l'application de la sélection phénotypique pour la tolérance aux herbicides et la mise en œuvre stratégique de ces techniques pour le development des lignées résistantes à herbicides est discutée. 
